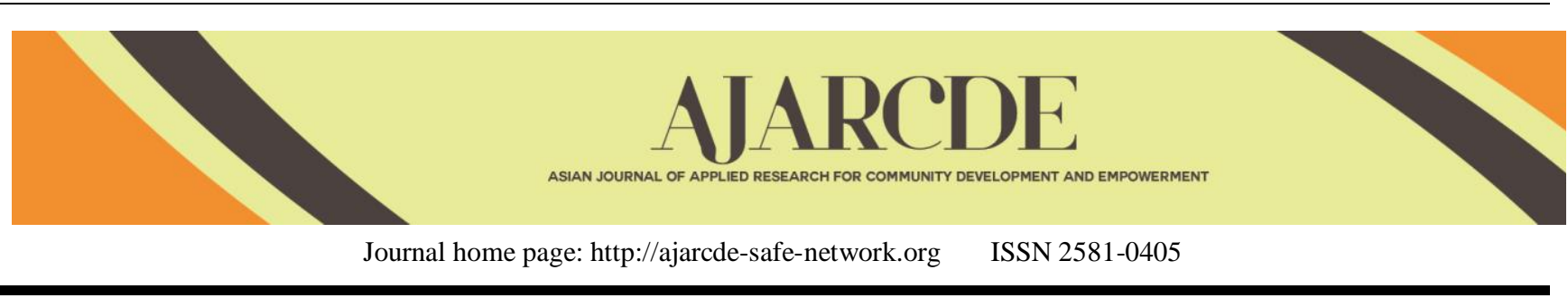

\title{
Effect of Variation of Catalyst Concentration in the Producing of Biodiesel from Crude Palm Oil using Induction Heater
}

\author{
Sandhy Yunsari ${ }^{1}$, A. Husaini ${ }^{2}$, Rusdianasari $^{*}$ \\ ${ }^{1}$ Renewable Energy Engineering Department, Politeknik Negeri Sriwijaya. Jl. Srijaya Negara Palembang, 30139, Indonesia. \\ ${ }^{2}$ Chemical Engineering Department, Energy Engineering Study Program, Politeknik Negeri Sriwijaya. Jl. Srijaya Negara Palembang, 30139, Indonesia. \\ *Corresponding author: rusdianasari@polsri.ac.id
}

\section{ARTICLE INFO}

Article History:

Received: July 29, 2019

Final Revision: November 24, 2019

Available Online: December 21, 2019

\section{KEYWORDS}

biodiesel, CPO, catalyst weight, induction heater

\section{CORRESPONDING AUTHOR}

*E-mail: rusdianasari@polsri.ac.id

\section{A B $\mathbf{S}$ T $\mathbf{R}$ A $\mathbf{C}$ T}

Biodiesel is an alternative fuel for diesel engines produced by transesterification and esterification of vegetable oils or animal fats with short chain alcohols such as methanol. The reaction requires a catalyst, which is generally a strong base, thus producing a new chemical compound called methyl ester. One of the most common sources of biodiesel feedstock is CPO (Crude Palm Oil). CPO production in Indonesia is very high at 30.2 million tons in 2016, but CPO prices are low. Biodiesel can be produced using conventional methods, this method is less efficient because of its very slow and inefficient heating resulting from the transfer of energy to materials that depend on the convection currents and the thermal conductivity of the reaction mixture) which causes researchers to use new methods of producing Biodiesel, that is by using induction heating method. An induction heater is a technology that has been applied both in industry and households. The weight of the catalyst used uses variations of $0.6 ; 0.8 ; 1.0 ; 1.2$; $1.4 \%$. The analysis showed that for optimal catalyst weight of $1.4 \%$, yield biodiesel of $83.94 \%$, density of $0.875 \mathrm{~g} / \mathrm{cm}^{3}$, the viscosity of $5.78 \mathrm{cSt}$, and flash point $>100^{\circ} \mathrm{C}$. The use of $1.4 \%$ catalyst concentration produced biodiesel product that has a high yield and according to SNI 7128: 2015

\section{INTRODUCTION}

Biodiesel is one of the biomass fuels that can replace oil fuel. One of the advantages of biodiesel fuel is more environmentally friendly than fossil fuels because biodiesel significantly reduces greenhouse gas emissions compared to fossil fuels. According to Indoenergi, one of the sources of biodiesel raw material that is often used is Crude Palm Oil (CPO). CPO production in Indonesia is very high, reaching 30.2 million tons in 2016, but CPO prices are low, so that is why we need to diversify the use of CPO. One of the diversification ways that can be done is the conversion of $\mathrm{CPO}$ into biodiesel.

$\mathrm{CPO}$ is vegetable oil (plant-derived oil) with reddish-orange color obtained from the process of pressing or extracting the flesh of the fruit of the Elaeis guineensis plant and has not undergone a refining process [1]. The quality of palm oil is determined by its constituent components, such as triglyceride components and minor components. Composite components of CPO consist of a mixture of triglycerides and other components, which are minor components [2]. Triglycerides are esters of glycerol and long chain fatty acids. Triglycerides can be solid or liquid at room temperature, depending on the composition of the fatty acid constituent. To convert the oil molecule into biodiesel, a method that can convert oil in high quantities is needed. One alternative method that can be used in producing biodiesel is the use of induction heaters.

Induction heaters are technologies that have been applied both in industry and households. One of the equipments that has used induction as a heater is an induction cooker [3]. Induction Heating, in principle, can be explained by the working principle of the transformer. The transformer works because of the phenomenon of electromagnetic induction, which, when there is a closed circuit in which Alternate Current (AC) flows, produces an electromagnetic field that changes accordingly [4]. As happens in the transformer, the electromagnetic fields (in the primary coil) that change affect the secondary coil and the secondary coil arises the electromotive force (emf) induction and flows of alternate current if the secondary coil is a closed circuit [5-7].

\section{MATERIALS AND METHODS}

\subsection{Material}

The raw materials of CPO used are obtained from a company that analyzes CPO to be produced into further ingredients. The 
catalyst used was sodium hydroxide with variations of $0.6 ; 0.8$; $1.0 ; 1.2 ; 1.4 \%$.

\subsection{Methods}

The first step of biodiesel production is the characterization of the CPO sample. After that, the raw material is washed with water $\left(\mathrm{T}=60^{\circ} \mathrm{C}\right)$ and preheated with a temperature of $<100 \mathrm{oC}$. After completing this stage, a transesterification process was carried out by mixing CPO with catalysts and methanol in a reactor using induction heating at a temperature of $60 \mathrm{C}$ for 15 minutes. The methyl esters that have been produced are then separated in the separator from the by-products of glycerol and followed by the process of washing methyl esters using warm water $\left(60^{\circ} \mathrm{C}\right)$. The heated methyl ester then analyzed its characteristics to determine its quality and compared it with SNI 7128: 2015. Instrumentation that is used in this research can be seen in Figure 1.

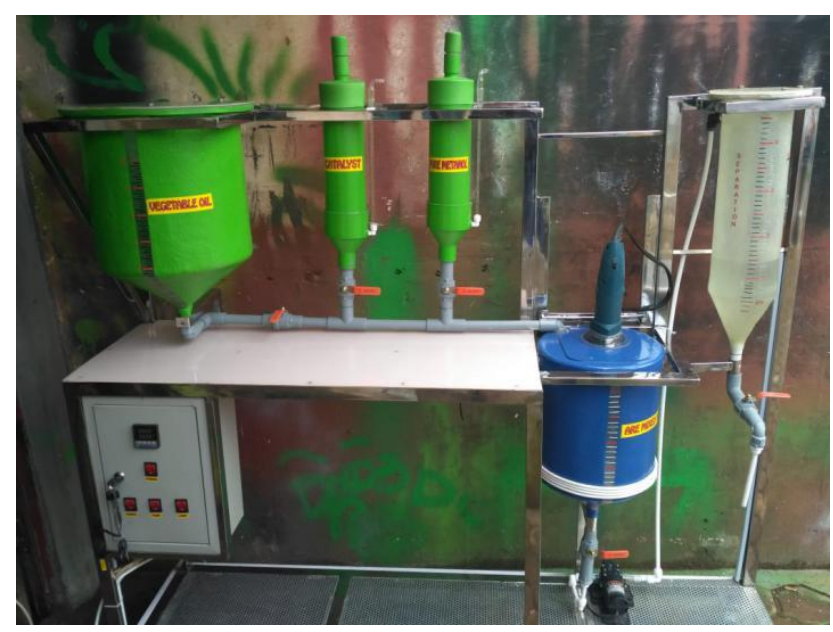

Figure 1. Biodiesel Production using Induction Heater Instrumentation

\section{RESULT AND DISCUSSION}

\subsection{Effect of catalyst concentration on yield biodiesel}

In this research a variation of catalyst $0.6 ; 0.8 ; 1.0 ; 1.2 ; 1.4$ was used to get the percentage of yield intended in Figure 2 shows that the greater the weight of the catalyst, the higher the yield of biodiesel at the fixed reactant ratio. With the increase in the number of catalysts, it will increase the reaction speed so that the yield of the biodiesel produced increases. Large amount of catalyst will further reduce the activation energy so that it increases the number of activated molecules increasing reaction speed. The catalyst functions to accelerate the reaction by reducing activation energy but does not affect the location of equilibrium [8]. Also, the use of large amounts of alkaline catalysts can neutralize free fatty acids in triglycerides. The optimum concentration of catalyst causes the free fatty acids that react with the catalyst increasing so the number of acidic products becomes lower. The higher number of base catalysts used, the more methyl esters formed [9].

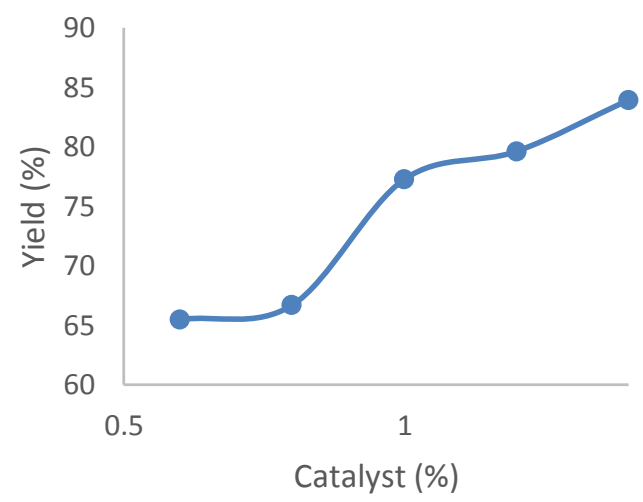

Figure 2. Relationship Between Catalyst Weight and Biodiesel Yield

The emulsion formed is caused by a side reaction that occurs due to excessive use of the catalyst. The saponification reaction will take a number of methyl esters that have been formed [10]. It will reduce the acquisition of biodiesel and make it difficult in the separation of biodiesel [11].

\subsection{Effect of catalyst concentration on the density}

Density is related to the heat value and power produced by a diesel engine. The relation between catalyst and flash point can be seen in Figure 3..

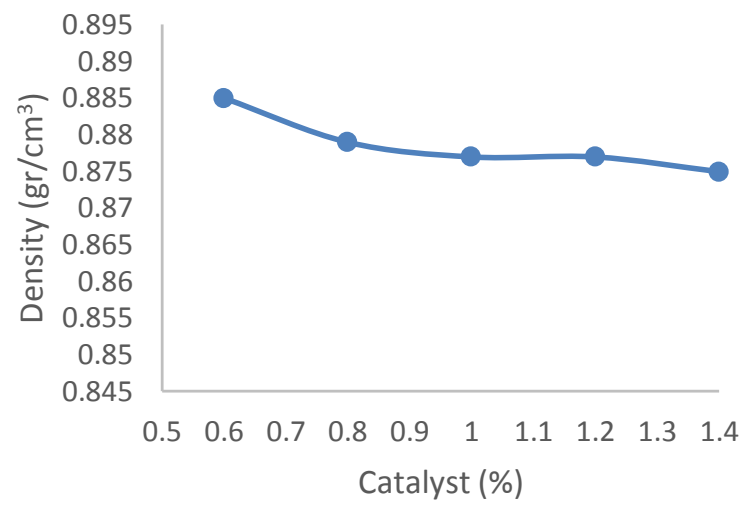

Figure 2. Relationship Between Catalyst Weight and Density

Low density will produce a high calorific value. It can be seen that the greater the catalyst added, the lower the density produced. In the $1.4 \%$ experiment, the catalyst was produced at 0.875 $\mathrm{gr} / \mathrm{cm}^{3}$. This is due to the termination of the glycerol chain found in $\mathrm{CPO}$.

\subsection{Effect of Catalyst Concentration on Biodiesel Viscosity}

Viscosity is a measure of the thickness of a fluid that shows the size of the internal friction of a fluid. The viscosity of the fluid is related to the friction force between the fluid layers when one layer moves pass the other layer [14]. The relation between catalyst and viscosity can be seen in Figure 4. 


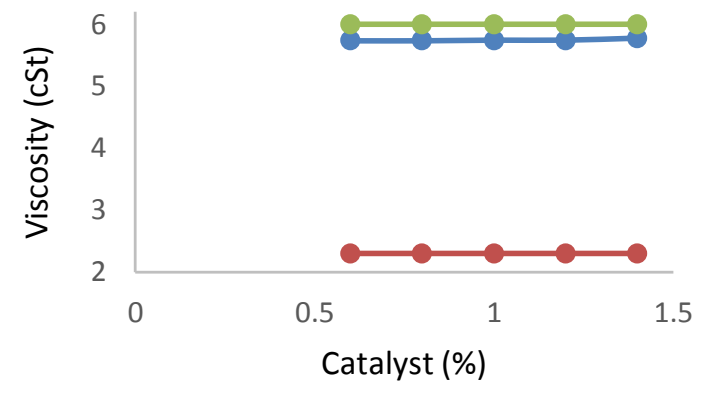

$\longrightarrow$ Research data $\longrightarrow$ minimum $\longrightarrow$ maximum

Figure 3. Relationship of Catalyst Concentration to Viscosity

\subsection{Effect of Catalyst Concentration on Biodiesel Flashpoint}

Flash points are states that will cause a moment ignition if the surface is brought near to the flame [13]. The relation between catalyst and flash point can be seen in Figure 5.

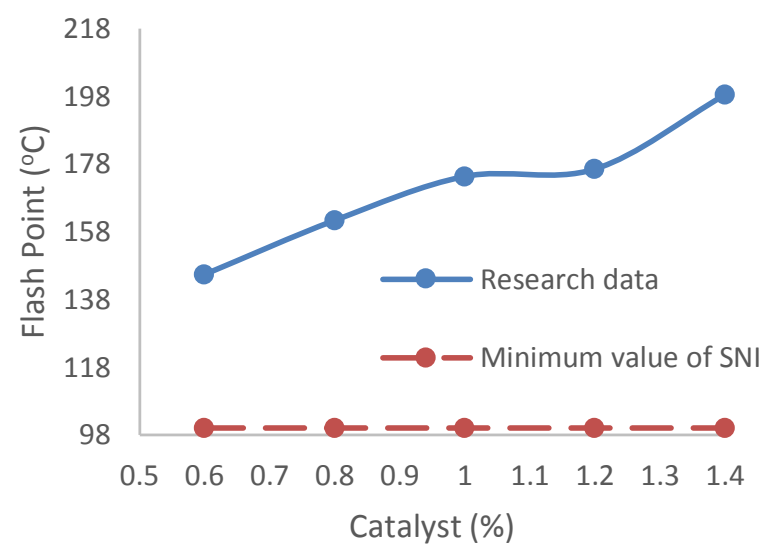

Figure 4. Relationship Between Catalyst Concentration and the Flashpoint

Flash points are needed for security considerations from stockpiling and transporting fuel oil to hazards fire [14-15]. Flash points for biodiesel are generally high (i.e., greater than $150^{\circ} \mathrm{C}$ ). The limits for SNI are $100-170{ }^{\circ} \mathrm{C}$. The flash point value produced is $81.5^{\circ} \mathrm{C}$, so if it is seen from the biodiesel flash point value, it does not meet the SNI standard, where the value is at least $100^{\circ} \mathrm{C}$. This is the lack of optimal purification process so that there is still a methanol content in the biodiesel produced. With this alcohol, it can cause damage to the fuel pump, tank filling, elastomer, and can produce low combustion power.

\section{CONCLUSION}

Induction heating is a non-contact, non-contact heating method that can change precisely determined parts of cherry red metal rods in seconds. When an alternating current flows in the induction coil, various electromagnetic induction fields are arranged around the coil, circulating currents (induced, currents, eddy currents) are produced in the workpiece (conductive material), and heat is produced as eddy currents flowing towards material durability. An induction heating method is a form of fast, clean, and non-polluting heating that can be used to heat metals or change the nature of conductive materials. The coil itself does not heat up, and the heating effect is controlled. Use of induction heating with a catalyst weight ratio $0.6 ; 0.8 ; 1.0 ; 1.2 ; 1.4 \%$ yields biodiesel yield of $83.94 \%$, density of $0.875 \mathrm{gr} / \mathrm{cm} 3$, the viscosity of $5.78 \mathrm{cSt}$ and flash point $>100^{\circ} \mathrm{C}$. The use of the weight of the catalyst produces $\%$ yield according to SNI in the manufacture of Biodiesel.

\section{REFERENCE}

[1] R. Ploetz, R. Rusdianasari and E. Eviliana. Renewable Energy: Advantages and Disadvantages. Proceeding Forum in Research, Science, and Technology (FIRST). 2016.

[2] Yusmartini, E.S. and Rusdianasari. Separation Process Biodiesel from Waste Cooking Oil using Ultrafiltration Membranes. Proceeding Forum in Research and Technology (FIRST), pp B10-B13. 2016.

[3] Refaat, A. A. dan El Sheltawy S. T., Time Factor in Microwave-Enhanced Biodiesel Production, Chemical Engineering, Engineering Faculty, Kairo University. 2008.

[4] Perdana, Alim Nur, Analisis Waktu Pemanasan Terhadap Karakteristik Bahan yang Berbeda oleh Pemanas Induksi, Jurusan Pendidikan Teknik Mesin Fakultas Teknik Universitas Negeri Medan, 2018 (in Indonesia)

[5] Greg Sorensen, David Zabrowski, Improving Range-Top Efficiency with Specialized Vessels, Appliance Magazine. August 2009.

[6] Erniati Anzar, M. Syahirman Yusi and Y. Bow, "Purification of Crude Gycerol from Biodiesel Byproduct by Adsorption using Bentonite', Indones. J. Fundam. Appl. Chem., Vol. 3(3), 2018.

[7] Karnanim, Sintesis Biodiesel dari Bahan Baku Minyak Sawit Menggunakan Reaktor Jet Bubble Coloumn, Universitas Indonesia, 2010 (in Indonesian).

[8] Mostapa R. A., Mohamed A.A, and Sherouk M. I. Insight into the Catalytic Conversion of Palm Oil into Biodiesel using $\mathrm{Na}^{+} / \mathrm{K}^{+}$Trapped Muscovite Composite as a Novel Catalyst: Effect of Ultrasonic Irradians and Mechanism. Renewable and Sustainable Energy Reviews 115 (109346. 2019.

[9] Sophie A. A., Richard J. M., and Robert S.W. Methodological Analysis of Palm Oil Biodiesel Life Cycle Studies. Renewable and Sustainable Energy Reviews 94(694-704. 2018.

[10] Indika Thushari, Sandhya Babel, Chanatip Samart, Biodiesel production in an autoclave reactor using waste palm oil and coconut coir husk derived catalyst, Renewable, doi: 10.1016/j.renene.2018.11.030. 2018.

[11] S.O. Kareem, S.A. Balogun, S.O. Omrika, E.I. Falokun, and Q.A. Akiniaye. Enzymatic Biodiesel production from Palm Oil and Palm Kernel Oil using Free Lipase. Egypti on Journal of Petroleum 26. 635-642. 2017. 
[12] Yunsari Sandhy, Husaini, and Rusdianasari, "CPO Based Biodiesel Production using Microwaves Assisted Method J. Phys: Comf.Ser. 1167 012036, 2019.

[13] Susumu, Rusdianasari, and S. Yusi, "Biodiesel Production from Waste Cooking Oil using Electrostatic Method', Indones. J. Fundam. Appl. Chem., Vol. 3(3), 2018.

[14] RAN Moulita, Rusdianasari, and L. Kalsum, "Converting Waste Cooking Oil into Biodiesel using Microwaves and High Voltage Technology," J. Phys: Comf.Ser. 1167 012033, 2019.

[15] J. U. Putra, L. Kalsum, and Y. Bow, "Effect of DC Voltage on Prototype of Biodiesel Electrostatic Separator with Glycerin from Waste Cooking Oil', Indones. J. Fundam. Appl. Chem., Vol. 3(3), 2018. 